Publié dans Children in Society, 2009,

DOI: 1111/j.1099-0860.2009.00283.x

\title{
After a long-term placement: Investigating behaviour, educational achievement and transition to independent living
}

\section{Annick-Camille Dumaret, Pascale Donati, Monique Crost}

Centre de Recherche Médecine, Sciences, Santé et Société

CERMES - INSERM Unité750

Corresponding Author: A.C. Dumaret

Email address: dumaret@ vjf.cnrs.fr

Telephone: $33 /$ 1.49.58.35.91

CERMES - INSERM U.750, 7 rue Guy Môquet, 94801 Villejuif cedex, France

\begin{abstract}
This study describes the transition towards independent living of 123 former fostered young people reared for long periods in a private French organisation, SOS Children's Villages. Three generations of care leavers were analysed through a postal survey and interviews. Their narratives show typical pathways after leaving care. Two thirds became independent without major problems by the age of 24-25. Analyses have shown that the absence of severe emotional and behavioural disorders, and diplomas obtained, improved their odds of becoming independent. Results suggest a vital need to implement appropriate therapeutic care during placement and to develop care leaver support well beyond the age of 18 , in order to help them personally and academically and to ensure their successful transition to adulthood.
\end{abstract}


Keywords: child welfare, placement, young people, leaving care, follow-up study, transition to adulthood 


\section{Introduction}

Changes in French child protection have contributed to improvements in foster care. However, debates have highlighted the lack of research on the quality of care services and on youth care leavers (Naves and others, 2003). A culture of evaluation has been gradually developing since the passing of a law on medical and social intervention in 2002 (Ministry 2006). Thus, a study on long-term outcomes of adults formerly reared in children's villages was conducted. The evolution of care services, and changes in the wider socio-economic context, have been taken into account, and an analysis was made of the period lasting from the end of care to the transition to independent living.

\subsection{Child protection and leaving care in France}

Child welfare services are under the responsibility of local authorities, and the Judicial Juvenile Protection department is under the responsibility of the state. These two sectors of child protection are independent but complementary. When educational assistance providing support to families on a voluntary basis (administrative measures) proves difficult to implement, children's judges can order judicial measures, which are revised every two years. Placements end when the children's judge so decides (the child returns home, generally with a family assistance measure), or when young people reach the age of majority. Child protection services may support them, and other young people without adequate family support networks, through agreements ("contrats Jeunes Majeurs"), until their $21^{\text {st }}$ birthday. Jeunes Majeurs represent $0.9 \%$ of the young people in their age group. They receive different forms of assistance to pursue educational or job training projects, and may remain in placement. But there is a four-year financial gap before they become eligible for welfare allowances at the age of 25. Since the mid-1980s, different support systems have been developed by communities, private foundations, and local authorities to fight social exclusion, particularly 
for young people aged 16-25 from poor socio-economic backgrounds, and/or with low educational levels. Results and key findings are still missing on a national or regional level.

\subsection{Transitions from care to adulthood and independent living}

International comparisons show different pathways for entry into adulthood, which are structured by welfare state interventions, education and family, and by the individuals themselves (Van der Velde, 2008). A recent book on research and practices in sixteen countries has shown the risk of social exclusion and marginalisation for former foster youth, despite significant disparities in policy and practices (Stein, Munro, 2008). Young care leavers undergo more accelerated transitions than their peers, who can generally count on dependable family support, and assistance from other networks (Stein, 2006). Furthermore, specific ethnic groups and isolated refugees face considerable challenges.

Many young care leavers have experienced multiple disruptions in their schooling, lack educational qualifications, and hold unskilled jobs (Broad, 1998; Courtney and others, 2001; Pecora and others, 2006; Wade, Dixon, 2006). In addition, several US and UK studies have highlighted care leavers' high rates of housing instability and youth homelessness, as well as of unplanned pregnancies and early parenthood (Carpenter and others, 2001; Pecora and others, 2006). Mental health problems (depression, stress disorders, alcohol and drug dependency...) have also been shown to have an impact on their access to the labour market and individual housing (Pinkerton, Stein, 1995; Lenz-Rachid, 2008). It was noted that the highest rates of poor social adjustment in early adulthood affect those who had multiplacements (Andersson, 2005; Wade, Dixon, 2006).

Some French studies using multidisciplinary approaches also reveal that care leavers have difficulty entering the workforce, work unskilled jobs, have weak networks, and lack preparation for independent living (Corbillon and others, 1997; Gheorghiu and others, 2002). Others focusing on individual pathways, noted the chain of transitions and have shown that 
high housing instability and mental health problems resulting in psychiatric hospitalizations largely decreased three years after leaving care (Frechon, 2005).

Research with long follow-up periods highlights the pervasiveness of offending behaviour and/or continued use of social services, particularly before services for care leavers existed (Festinger, 1983; Coppel, Dumaret, 1995, Dumaret, Coppel-Batsch, 1997). An analysis of 30 studies has shown a decrease in psychosocial difficulties and better social integration after the age of 25 (Frechon, Dumaret, 2008).

Evaluating the outcomes of care leavers requires taking into account experiences before entering care and events that occur during and after care. A large proportion of care leavers comes from troubled families, and has experienced neglect, abuse, as well as learning and behavioural difficulties. They have also experienced changes in placement and break-ups in their relationships, leading to insecure attachments. All these factors put them at greater risk of future difficulties. Consistent findings highlight the importance of placement stability, bonds with a key person, and societal and family support during the transition to adulthood (Biehal and others, 1995; Leathers 2006; Courtney, Dworsky 2006; Wade, Dixon 2006). Conditions of transition to adult independence have changed considerably during the last two decades. However, little attention has been paid to different generations of care leavers and their views of the transition period.

\subsection{The SOS children's villages study}

"SOS Children's Villages" (CVs) is an international non-governmental social development organization providing long-term care to children without parental care and to children from vulnerable families (100 CVs in Europe). In France today, 600 children and adolescents are being raised in $13 \mathrm{CVs}$ by foster caregivers (the "SOS mothers") working with a director, psychologists, case workers, and family helpers. CV staff were gradually hired during the mid-1980s, at a time when families in France were getting smaller. Prior to that period, SOS 
mothers volunteered for "philanthropic work" and raised large sibling groups. From the mid1980s on, the new SOS mother took on a more professional role in carrying out their duties. Most of them began to rear two groups of siblings together. At the same time (1985-90), services were created: a job training service, informal support (housing and job searches, administrative support), and transitional apartments and residential accommodation for adolescents or young adults. The objective was to prevent social exclusion, particularly for youth with mental health problems or disabilities, and those who had had run-ins with the law or disrupted careers, and more generally, to develop life training skills.

The CV study was designed to assess the social integration and quality of life during adulthood of former foster children and adolescents, as well as relationships with former foster caregivers and among siblings. A follow-up study in the past was conducted on an entire CV in the south of France from which 150 young people aged 15 and older left care between 1972 and 2000. Such a long period following discharge from care allowed us to examine the principal changes both in institutional practices and in the conditions of access to independence. The impact of parental pathologies and of maltreatment on behavioural problems was analysed in an earlier publication. This paper is focused on the transition period during which young people strove towards financial and housing independence. The purpose is twofold: a) to describe the evolution of forms of support provided to several generations of

care leavers; and b) to analyze educational outcomes and access to independent living. The results will be highlighted through the former foster youths' perceptions of their first years after support ended.

\section{Methods}

The population study $(\mathrm{n}=123)$ met the following three criteria: 1$)$ the subjects had been placed at least three years, 2) they had been discharged from care for over three years, and 3) they were at least 23 years old when the survey began. The research protocol was approved by 
the National Committee of Data-processing and Freedoms (Commission Nationale Informatique et Libertés).

\subsection{Materials}

Institutional files: Case records provided information on demographic data, individual situations at admission, care services, and annual scholastic and psychological appraisals. Important events during placement and after discharge, when young adults came back to ask for assistance, were also identified. Emotional and behavioural (EB) disorders during placement and until late adolescence were classified as follows: no significant disorders mentioned, mild disorders, and severe disorders (Dumaret, Crost, 2008).

Follow-up: In 2004, a survey was mailed to the 123 subjects aged 23-50 (median age: 38 ) to determine both their current social integration and their living conditions after discharge from care, including diplomas and access to housing. They were asked to be interviewed, and in 2005 and 2006, face-to-face interviews were conducted by psychologists who were unaffiliated with the institution and could assure interviewees that their reports would remain anonymous. An interview guide was used, covering several areas of their past and present lives. All but one of their SOS mothers were interviewed in the same manner.

Data collection enabled us to specify main difficulties care leavers had to cope with during the transition to independent living at approximately 24-25 years of age. Independence is defined here as self-sufficiency on a financial and material level (stable job held for six months, and independent housing) and being independent of any institutional support. Independence differs from the more subjective notion of "autonomy", also discussed in interviews, which refers to the ability to make one's choices alone (De Singly, 2001).

Thus, it has been possible to assess 114 transitional situations through the 123 institutional files, 99 questionnaires, and/or interviews with adults (73 adults formerly in care and 22 SOS mothers). 


\subsection{Analysis}

To take into account changes in the educational system, in child welfare practices, and in the wider socio-economic context, three time periods were chosen (Note 1). Change took place gradually, but such classification allowed us to distinguish among generations who experienced vastly different care and social constraints. The three groups were 1) those from the earliest P1 period: 30 subjects (mean age at survey: $45.0 ; \sigma=2.2$ ); 2) those from the middle P2 period: 65 subjects (mean age: $37.9 ; \sigma=2.5$ ); and 3 ) those from the most recent P3 period: 28 subjects (mean age: 27.0; $\sigma=3.7$ ). The oldest generations left care before 1980, the intermediate ones during the 1980s, and the youngest generations during the 1990s.

Bivariate statistical tests were used to test significant differences between analyzed groups. To take into account the effects of confounding factors, multivariate analyses by logistic regression were used to examine the specific role of decisive factors (SAS software, version 9.1). The variables tested in the multiple logistic regression are those showing a significant difference at the $\mathrm{p}<0.10$ level in the bivariate analysis. Adjusted odds ratio estimates $\left(\mathrm{OR}_{\mathrm{a}}\right)$ were considered to be significant at the $\mathrm{p}<0.05$ level. After transcription of the audio-taped interviews, content analysis was used to study several themes; a comprehensive analysis of perceptions of leaving care and entry into adulthood allowed us to reconstruct personal pathways and typical life experiences.

\section{Results}

\subsection{Characteristics of the young people}

Although death or disappearance of one or both parents had long been the principal reason for CV placement, other parental risk factors existed (alcohol, antisocial and mental health problems). Two thirds had previously been subjected to intra-family violence, and an identical proportion had been neglected and abused. Four out of ten had developmental delays, impairment, and various health problems, and half had experienced school failure. 
Three quarters of those admitted were older than six $(\mathrm{m}=8.8, \sigma=3.9)$; the majority left care at 18 , and a third did so at 19 or older $(\mathrm{m}=18.6, \sigma=1.5)$. The youngest generations were admitted earlier and their CV placement was prolonged beyond the age of majority. The average placement was long $(\mathrm{m}=9.8, \sigma=4.1)$.

\section{Table 1}

The proportion of youths with EB disorders was stable throughout the three periods; half received regular educational and therapeutic support (minimum: one year) in the $\mathrm{CV}$ or in day-care centres (Table 1). During the P2 period, with the growing number of staff members, care services increased (psychological support, after-school activities), and support services for adolescents were diversified. Family support during the transition period (financial help, housing) was also significant (59\%).

A third of those from the younger generations received a high school diploma or higher, while the older ones obtained more technical diplomas and apprenticeship certificates. However, four out of ten of all the youths had no diploma. A quarter of the diplomas were obtained thanks to prolonged support after the age of the majority, particularly among the youngest generations of care leavers (43\% during P3 vs. 20\% during $\mathrm{P} 1 / \mathrm{P} 2, \mathrm{p}<0.02$ ).

EB disorders had an impact on their schooling: two thirds of those with severe disorders and mental health problems had no diploma. Nevertheless, the disorders had an impact on the age of leaving care: a quarter of those with severe EB disorders left care earlier than the others. Nine adolescents returned to their biological families before the age of 17 ; the family reunifications failed, and the majority of these adolescents were placed elsewhere or requested child welfare services. The other departures involved young men with antisocial behaviour and/or those who performed their military service, and young women who left care to be closer to their families or to set up a home with a partner after running away. 
Nearly four out of ten subjects did not live in individual housing in the first years following their discharge, living instead with their family, friends, or in residential lodging. Housing independence was attained more rapidly by young adults with diplomas (74\% vs. $43 \%$ for those without diplomas, $\mathrm{p}<0.001)$ and by those without disorders $(79 \%$ vs. $40 \%$ with severe problems, $\mathrm{p}<0.002)$. Across the three generations of care leavers, two thirds of young adults began living independently towards the age of 24-25 without encountering major problems; it was more difficult for a quarter of them, and one tenth was still not independent..

\subsection{Factors associated with independent living towards the ages of 24-25}

The most significant characteristics in determining access to independence were linked to gender (women were more successful than men), family and child risk factors before admission (domestic violence, developmental delay, abuse), EB disorders, and diplomas.

Table 3

Detailed analysis has shown that, of the 27 youths who had a difficult time becoming independent, one out of three had psychiatric problems (eight men and one woman), and a similar proportion obtained a diploma. The situation was worse for those who were not independent: 10 out of 13 (six men and four women) had psychiatric problems, and only one had a training diploma.

Multiple logistic regressions were carried out on the outcome variable: independent living without major problems. A first step was conducted by simultaneously taking into account the ex-care periods, parental risk factors, gender, and neglect and abuse before placement. Four factors were significantly associated with independence: absence of developmental delay at admission $\left(\mathrm{OR}_{\mathrm{a}}=8.27\right)$, sex $\left(\mathrm{OR}_{\mathrm{a}}=4.03\right)$, absence of abuse $\left(\mathrm{OR}_{\mathrm{a}}=3.48\right)$, and absence of parental psychiatric problems $\left(\mathrm{OR}_{\mathrm{a}}=3.25\right)$.

Table 4 
In the second step, disorders and diplomas were added to the test (Table 4). After adjustment for the ex-care periods and developmental delay, only two factors significantly improved the odds of independence. The $\mathrm{OR}_{\mathrm{a}}$ were high for youths who showed no sign of severe EB disorders. Having a diploma also improved the odds of becoming independent; the higher the level, the greater the effect.

In the first years after leaving care, we estimated that $16-20 \%$ of young adults (the majority were men) experienced violent episodes, behavioural problems, and alcohol and/or drug dependence. As shown by the interviews, the majority of these problems were temporary, with the exception of those caused by severe mental health problems.

\subsection{Life after care: young people's perceptions}

Discussions about the period during which subjects had left the familiar CV environment led to ambivalent feelings: the satisfaction of being free, coupled with feelings of isolation. Most remember having been motivated by projects and an eagerness to take on adult roles (working, starting a family). The majority of interviewees felt that they quickly became autonomous, approximately two years after their departure. For the older generations, feelings of autonomy were linked to their financial independence, while in younger generations they were tied to their ability to manage their emotional lives and to distance themselves from life in the CV family framework. Yet a few, especially men, claimed to have had no project or support; they presented their experiences as chaotic and said they became independent later, or only partially independent for those with a poor sense of mental well-being.

Family solidarity was a key point in the narratives; emotional and material support provided by their main caregiver, the SOS mother, was mentioned first. Those who became parents, even those who had broken off all contact after leaving care, expressed how they were able to count on her when their own children were born. For the oldest, most support 
came from their eldest brothers and sisters (large families). For all of them, job training support and transitional apartments were held up as examples of decisive support providing the first steps towards autonomy and entry into adulthood within a supervised setting.

\subsection{Typical experiences}

Beyond individual experiences, three types of personal history patterns could be identified, revealing different processes used to reach independence.

3.4.1. Making do and dealing with "old-fashioned hardships"

Such patterns are typical of the older generations of care leavers. This period represented a break with the institution and/or their foster caregiver (the SOS mother), when they were easily able to get a job, even without a diploma: "I had set a goal for myself: find work, earn money, and find a wife. It wasn't easy, but I held in there [...] I slept in a car for several months, and by working I was able to integrate myself into to the community." (A man in his forties).

\subsubsection{Halting progress for the youngest generations}

Like most people in their age group living through transitional situations, the youngest generations of care leavers made halting progress, alternating between dependence on the institution or their caregivers and partial autonomy, with high residential mobility. Their statements highlight their personal fragility and identity research. The separation from the SOS mother took place in a more gradual way, in which the attachment lasted longer: " $I$ carry the trauma of the separation from her" (a 25 year-old man). Sometimes, this attachment was tied to a depressed state: "My mother was always there to house me, and the village was offering me work... There was a period when I was trying to find myself; I was a bit depressed and felt unhappy, so I decided to go see a neuropsychiatrist lady." (A 29 year-old man who transitioned slowly to independence).

\subsubsection{Gradual social integration process}


The most common pathway was a gradual or halting transition, without long-lasting or repeated hardships. There were fewer generational differences than gender differences in these experiences, with relationships marking the first step towards autonomy for women. However, a large majority of women who left care before the mid-1980s said that their professional activity was a more decisive factor in their experience than their relationships and family lives: “As soon as I obtained my training diploma, I looked for work everywhere! [...] Afterwards, I had a boyfriend, but for two years there were highs and lows. I almost lost my job; I almost ended up on the street... I tested quite a few things out, in other words! We make mistakes and it allows us to move forward. " (A 36 year-old woman)

However, even during these transitions, all felt fairly powerless when confronted with the demands of daily life, as was the case with a 24 year-old man: "Fitting in after leaving the $C V$ was hard: taking mass transit, budgeting, registering at the social security office..."

\section{Discussion and Perspectives}

SOS children's villages offer long-term placement through their family units and important care services to children and siblings' groups. This study is the first to describe the entry into adulthood of several generations of care leavers raised for a long time in foster care. The high rate of participation in this study reflects both their motivation to talk about their life experiences and their wish that their reflections on the strengths and weaknesses of this type of foster care be helpful to others.

For the older generations, the institutional services and support provided were minimal. Nevertheless, they benefited from a favourable labour market, even for those with low qualifications. The middle generations witnessed changes in school policy; care services were developed and diversified, essentially from the mid-1980s. Support proved to be all the more necessary as the youngest generations were confronted with devalued lower-level diplomas 
and worsening labour market entry conditions.

The large majority underwent transitions and successfully began living independently by the age of 24-25. Their social integration processes ranged from chaotic to gradual, as mentioned by the interviewees. The high proportion can be linked to placement stability and to continuing care services, whatever the age of departure. Such prolonged support, sometimes beyond the age of 21 , allowed a quarter of young people to obtain diplomas. High levels of support from their siblings and from their foster caregivers (the SOS mother, the educators) were reported. Such relationships and attachment may have been protective factors to cope with transitional problems and exclusion risks; supportive partners were also mentioned in their narratives (Biehal, 1995; Coppel, Dumaret, 1995; Jahnukainen, 2007; Wade, 2008). With the abrupt withdrawal of support for some troubled care leavers before 1718 , experiences were similar to those described by research on young runaways or on young people from child welfare services: antisocial behaviour, violence, admission to mother-child hostels (Marpsat, Firdion, 2001).

Disparities exist among child welfare services, agencies, and populations in care. In spite of the fact that results cannot be applied to other placements, one may suppose that better experiences produce better outcomes. Young people from Judicial Juvenile Protection faced more difficulties in their transitions (Hubert and others 2006). Other limitations to this study should be noted. Regarding behavioural and mental health problems: without standardized measures, precautions in interpreting results are necessary; the collected data remain descriptive. As for these adults' memories of their journey to adulthood and independent living, some problems may have been forgotten by those who are satisfied with their current situation.

Some concerns over these results are shared by both SOS children's villages and child welfare services. Two issues which need to be dealt with together are the percentage of 
children and adolescents placed in care that show signs of behavioural and mental health problems, and the proportion of young carers without diplomas:

- Today, half of these adults now regret having left school too early, which suggests that young people had not seized opportunities offered during placement, as shown in other studies (Trout and others, 2008; Vacca 2008). Children in care should be encouraged to finish school.

- We had noted in a previous publication that severe disorders were persistent, especially among children and adolescents who had been multiplaced before their admission in Children's Villages (Dumaret, Crost, 2008). Improvements in psychological assessment are being strongly urged by foster care specialists, particularly to identify young people at risk of severe difficulties, and to implement appropriate therapeutic care if necessary (Berger 2003).

Thus, prolonging all support after the age of 18 , and even 21 , is essential to help young people explore career options and obtain a diploma, particularly for those with little schooling and for adolescents with psychiatric problems.

Formerly, most of the SOS mothers were perceived as adoptive parents by the children or groups of siblings they had reared. The professionalisation of foster care has transformed their task (they officially became family educators in 2005) and has brought into question their long-term relationships with young people. While bonds will endure with some young people who need long-term placement, it remains to be seen whether these caregivers will be able to continue providing tangible support to the others.

Whatever the leaving care period, feelings of isolation were mentioned by many, even when transitions were free of major problems. All noted the necessity of developing life skills during placements. Some research has shown that, despite assistance in this area, a third of young care leavers reported feeling unprepared to live on their own (Courtney and others, 2001). 
Important changes in child welfare policies took place over the course of a decade: the decreasing length of placement and greater instability in children's lives, the failure of many family reunifications, the increase in measures for home assistance and support services to help parents assume their responsibilities, greater attention given to users of child welfare services. These tendencies increase the need to re-think innovative frameworks for ongoing supportive relationships (referents or mentors). Such programs have been developed in other countries and in a very small number of French départements (Lemon and others, 2005; Goyette 2006; Reid, Dudding, 2006; Osterling, Hines 2006). To be effective, all services and professionals must coordinate their actions through a coherent platform to prevent these young people from being "lost in transition". More research with quantitative and qualitative approaches is needed to improve standards of care and the lives of children and adolescents in care.

Note 1: Professional high school diplomas were created in 1985. Improving levels of instruction were accompanied by the devaluation of diplomas received. The age of majority went from 21 to 18 in 1974. Compulsory military service ended in 1998.

\section{Acknowledgments}

Research was supported by grants from the SOS Children's Villages organization, the board of the Ministry of Social Cohesion, Health and Solidarity, and the Wyeth Foundation. We would like to thank Marie Constantin-Kuntz and Catherine Mousseau, psychologists who conducted some of the interviews. We extend special thanks to Professor Mike Stein of the University of York, UK, for his comments and review of an earlier draft. 


\section{References}

Andersson G. 2005. Family relations, adjustment and well-being in longitudinal study of children in care. Child and Family Social Work 10: 43-56.

Berger M. 2003. L'échec de la protection de l'enfance. Paris, Dunod.

Biehal N, Clayden J, Stein M, Wade J. 1995. Moving on: Young people and leaving schemes. Her Majesty's Stationery Office, London.

Broad B. 1998. Young people leaving care: Life after the Children Act 1989. London: Jessica Kingsley Publishers.

Carpenter SC, Clyman RB, Davidson AJ, Steiner JF. 2001. The association of foster care or kindship care with adolescent sexual behavior and first pregnancy. Pediatrics 108(3), p. e46.

Coppel M, Dumaret AC. 1995. Que sont-ils devenus ? Les enfants accueillis à l'Oeuvre Grancher. Analyse d'un placement familial spécialisé. Ed. Erès, Ramonville St Agne.

Corbillon M, Duléry A, Mackiewicz MP. 1997. Quel devenir à l'issue d'un placement dans une maison d'enfants? Rapport final de recherche. Orléans: GERIS.

Courtney ME, Piliavin I, Grogan-Kaylor A, Nesmith A. 2001. Foster youth Transitions to Adulthood: A Longitudinal View of Youth Leaving Care. Child Welfare 6: 685-717.

Courtney ME, Dworsky A. 2006. Early outcomes for young adults transitioning from out-ofhome care in the USA. Child and Family Social Work, 11: 209-219.

Del Valle JF, Bravo A, Alvarez E, Fernanz A. 2008. Adult self-sufficiency and social adjustment in care leavers from children's homes: A long-term assessment. Child and Family Social Work 13: 12-22.

Dumaret AC, Crost M. 2008. Placements à long terme en villages d'enfants depuis plus de 30 ans: troubles psychiques et prises en charge. Neuropsychiatrie de l'Enfance et de l'Adolescence 56: 512-519.

Dumaret AC, Coppel-Batsch M, Couraud S. 1997. Adult outcome of children reared for long term period in foster families. Child Abuse Neglect, 21: 911-927.

Festinger T. 1983. No one ever asked us. A postscript to foster care. New-York: CUP.

Frechon I. 2005. Stratégies féminines d'entrée dans la vie adulte après un placement à l'adolescence ». In E. Callu, JP Jurmand,, A. Vulbeau (Eds.), La place des jeunes dans la cité (pp. 215-232), Tome 2, Paris: L'Harmattan. Espaces de rue, espace de parole.

Frechon I, Dumaret AC. 2008. Bilan critique de 50 ans d'études sur le devenir des enfants placés. Neuropsychiatrie de l'Enfance et de l'Adolescence, 56, 135-147.

Gheorghiu M, Labache L, Legrand C, Quaglia M, Rafanell I Orra J, Teixeira M. 2002. Devenir des personnes sorties de l'ASE en Seine-Saint-Denis entre 1980 et 2000. Rapport final de recherche au Conseil Général, Bobigny.

Goyette M. 2006. Préparation à la vie autonome et l'insertion socioprofessionnelle des jeunes pris en charge par l'Etat : quelles interventions ? Revue Sociétés et jeunesses en difficulté. On line: http://sejed.revues.org/document159.html.

Hubert T, Tournyol du Clos R., Cosio M., Frechon I. 2006. - Le devenir des jeunes pris en charge par les services de la PJJ . Rapport final, CERPOS, CNFE-PJJ.

Jahnukainen M 2007 High-risk youth transitions to adulthood: A longitudinal view of youth leaving the residential education in Finland. Children and Youth Services Review 29: 637-654. Leathers SJ. 2006. Placement disruption and negative placement outcomes among adolescents in long-term foster care: the role of behaviour problems. Child Abuse Neglect 30: 307-324.

Lemon K, Hines AM, Merdinger J. 2005. From foster care to young adulthood: The role of independent living programs in supporting successful transitions. Children and Youth Services Review 27: 251-271.

Lenz-Rashid S. 2008. Employment experiences of homeless young adults: Are they different fro youth with a history of foster care? Children and Youth Services 28 : 235-259. 
Marpsat M., Firdion JM. 2001. Les ressources des jeunes sans domicile et en situation précaire. Recherches et Prévisions, 65: 91-112.

Ministère de l'Emploi, de la Cohésion sociale et du Logement, Ministère de la Santé et des Solidarités. 2006. Livret d'information pour les acteurs de la Protection de l'Enfance. La qualité et son évaluation, Paris.

Naves, P., Briand, C., \& Oui, A. (2003). Contribution à l'amélioration du système français de Protection de l'Enfance. Rapport du groupe de travail Protection de l'enfance et de l'adolescence au Ministre délégué à la Famille, Paris.

Osterling KL, Hines AM. 2006. Mentoring adolescent foster youth: promoting resilience during developmental transitions. Child and Family Social Work 1: 242-253.

Pecora PJ, Kessler RC, O'Brien K, and others. 2006. Educational and employment outcomes of adult formerly placed in foster care: Results from the Northwest Foster Care Alumni. Children and Youth Services Review 28: 1459-1481.

Pinkerton J,, Stein M. 1995. Responding to the needs of young people leaving state care: Law, practice and policy in England and Northern Ireland. Children and Youth Services Review 5/6: 683-695.

Reid, C., \& Dudding P. (2006). Building a future together: Issues and outcomes for transition-aged youth, Centres of excellence for children's well-being, Ottawa, $58 \mathrm{p}$.

Sinclair I, Baker C, Wilson K, Gibbs I. 2005. Foster children: where they go and how they get on. Jessica Kingsley, London.

Singly F de. 2001 Etre soi d'un âge à l'autre. Famille et individualisation (dir.). L'Harmattan, Logiques Sociales.

Stein M. 2006. Research Review: Young people leaving care. Child and Family Social Work 11: 273-279.

Stein M, Munro ER. Eds. 2008. Young people's transitions from care to adulthood: international research and practice (pp. 49-62). London: Jessica Kingsley Publishers.

Trout AL, Hagaman J, Casey K, Reid R, Epstein M. 2008. The academic status of children and youth in out-of-home care: A review of the literature. Children and Youth Services Review 30: 979-994.

Vacca JS. 2008. Foster children need more help after they reach the age of eighteen. Children and Youth Services Review 30 : 485-492.

Van de Velde (Cécile), Devenir adulte. Sociologie compare de la jeunesse en Europe. Paris, PUF, 2008.

Wade J, Dixon J. 2006. Making a home, finding a job: investigating early housing and employment outcomes for young people leaving care. Child and Family Social Work 11: 199208.

Wade J. 2008. The ties that bind: Support from birth families and substitute families for young people leaving care. British Journal of Social Work 38: 39-54. 
Table 1: Main characteristics and care leavers' generations

\begin{tabular}{|c|c|c|c|c|c|}
\hline \multirow[b]{2}{*}{ Placement, care services and independence } & \multirow{2}{*}{\multicolumn{2}{|c|}{$\begin{array}{c}\text { Total } \\
N=123\end{array}$}} & \multicolumn{3}{|c|}{ Leaving care period } \\
\hline & & & $\begin{aligned} \mathrm{P} 1<1980 \\
\quad N=30\end{aligned}$ & $\begin{array}{c}\mathrm{P} 2=1980-89 \\
N=65\end{array}$ & $\begin{array}{c}\mathrm{P} 3 \geq 1990 \\
N=28\end{array}$ \\
\hline & $n$ & $\%$ & $\%$ & $\%$ & $\%$ \\
\hline \multicolumn{6}{|l|}{ Age at admission } \\
\hline $0-5$ years & 31 & 25 & 3 & 28 & 43 \\
\hline $6-10$ years & 53 & 43 & 47 & 40 & 46 \\
\hline $11-16$ years & 39 & 32 & 50 & $\begin{array}{c}32 \\
\mathrm{p}<0.003\end{array}$ & 11 \\
\hline \multicolumn{6}{|l|}{ Age when discharge from care } \\
\hline$\leq 17$ years & 22 & 18 & 17 & 22 & 11 \\
\hline 18 years & 59 & 48 & 73 & 48 & 21 \\
\hline$\geq 19$ years & 42 & 34 & 10 & $\begin{array}{c}31 \\
\mathrm{p}<0.001\end{array}$ & 68 \\
\hline \multicolumn{6}{|l|}{ EB disorders during care and/or when leaving care } \\
\hline Exit & 35 & 28 & 37 & 29 & 18 \\
\hline No & 37 & 30 & 27 & 29 & 36 \\
\hline Mild & 51 & 42 & 37 & 42 & 46 \\
\hline Severe & & & & ns & \\
\hline After-school activities & 97 & 79 & 47 & $\begin{array}{c}88 \\
\mathrm{p}<0.001\end{array}$ & 93 \\
\hline Educational and psychological services (regular care) & 62 & 53 & 17 & $\begin{array}{c}54 \\
\mathrm{p}<0.001\end{array}$ & 86 \\
\hline $\begin{array}{l}\text { All leaving care services } \\
\text { Including }\end{array}$ & 75 & 61 & 43 & $\begin{array}{l}57 \\
p<0.001\end{array}$ & 89 \\
\hline - Housing services, transitional apartments & 23 & 19 & 3 & $\begin{aligned} 15 \\
p<0.001\end{aligned}$ & 43 \\
\hline - Young adult welfare services (contracts) & 33 & 27 & 0 & $\begin{array}{c}20 \\
\mathrm{p}<0.001\end{array}$ & 71 \\
\hline - Job training services and informal support & 48 & 39 & 13 & $\begin{array}{c}35 \\
\mathrm{p}<0.001\end{array}$ & 75 \\
\hline Family support (siblings, foster carers) & 70 & 59 & 50 & $\begin{array}{l}62 \\
\text { ns }\end{array}$ & 62 \\
\hline \multicolumn{6}{|l|}{ Highest diploma ${ }^{(1)}$ obtained } \\
\hline High school or university diploma & 19 & 15 & 10 & 11 & 32 \\
\hline Youth training & 51 & 41 & 57 & 37 & 36 \\
\hline No diploma & 53 & 43 & 33 & $\begin{array}{c}52 \\
\left(\mathrm{p}<0.03^{(2)}\right)\end{array}$ & 32 \\
\hline \multicolumn{6}{|l|}{ Independent housing } \\
\hline Individual housing at the outset & 36 & 31 & 43 & 29 & 23 \\
\hline Independent by second ex-care home & 35 & 30 & 30 & 32 & 27 \\
\hline Still not in individual housing & 44 & 38 & 27 & $\begin{array}{l}39 \\
\mathrm{~ns}\end{array}$ & 50 \\
\hline \multicolumn{6}{|l|}{ Independent living } \\
\hline Yes, without serious problems & 74 & 65 & 78 & 66 & 50 \\
\hline With difficulty or not independent & 40 & 35 & 22 & 34 & 50 \\
\hline & & & & ns & \\
\hline
\end{tabular}

(1) diplomas were classified as follows: a) high school diploma (baccalaureate for general education or vocational diploma of equivalent level) and/or years in university, b) youth training or less than 3 years of high school (equivalent to 4 years in a French secondary school), c) no diploma, including low-level certificates in general education or apprenticeships. 
(2) small numbers; but the youngest care leavers' generations obtained significantly more frequently high school or university diploma than the oldest ones $(\mathrm{p}<0.01)$.

Table 2: Access to independent living by demographic, educational characteristics and EB Disorders

\begin{tabular}{|c|c|c|c|c|}
\hline & \multicolumn{4}{|c|}{ Independent living } \\
\hline & & Without serious & With difficulty & \\
\hline & Total & problems & /not independent & \\
\hline & $N=114$ & $N=74$ & $N=40$ & \\
\hline & $n$ & $\%$ & $\%$ & $\mathrm{p}$ value \\
\hline \multicolumn{5}{|l|}{ Gender } \\
\hline Male & 58 & 53 & 47 & \\
\hline Female & 56 & 77 & 23 & $\mathrm{p}<0.01$ \\
\hline \multicolumn{5}{|l|}{ Domestic violence } \\
\hline No & 36 & 83 & 17 & \\
\hline Yes & 75 & 57 & 43 & $\mathrm{p}<0.01$ \\
\hline \multicolumn{5}{|l|}{ Neglect and abuse } \\
\hline No maltreatment & 40 & 75 & 25 & \\
\hline Neglect (without abuse) & 34 & 68 & 32 & $\mathrm{NS}^{(1)}$ \\
\hline Abuse (with or without neglect) & 40 & 52 & 48 & \\
\hline \multicolumn{5}{|l|}{ Developmental delay before admission } \\
\hline No & 97 & 71 & 29 & \\
\hline Yes & 17 & 29 & 71 & $\mathrm{p}<0.001$ \\
\hline \multicolumn{5}{|l|}{ EB disorders } \\
\hline No & 31 & 84 & 16 & \\
\hline Mild & 36 & 83 & 17 & $\mathrm{p}<0.001$ \\
\hline Severe & 47 & 38 & 62 & \\
\hline \multicolumn{5}{|l|}{ Highest diploma obtained } \\
\hline High school or university diploma & 19 & 89 & 11 & \\
\hline Youth training & 50 & 78 & 22 & $\mathrm{p}<0.001$ \\
\hline No diploma & 45 & 40 & 60 & \\
\hline
\end{tabular}

(1) The comparison "abuse $v s$. no maltreatment or neglect" is significant $(\mathrm{p}<0.05)$ 
Table 3: Determinant factors in access to independence (logistic regression model)

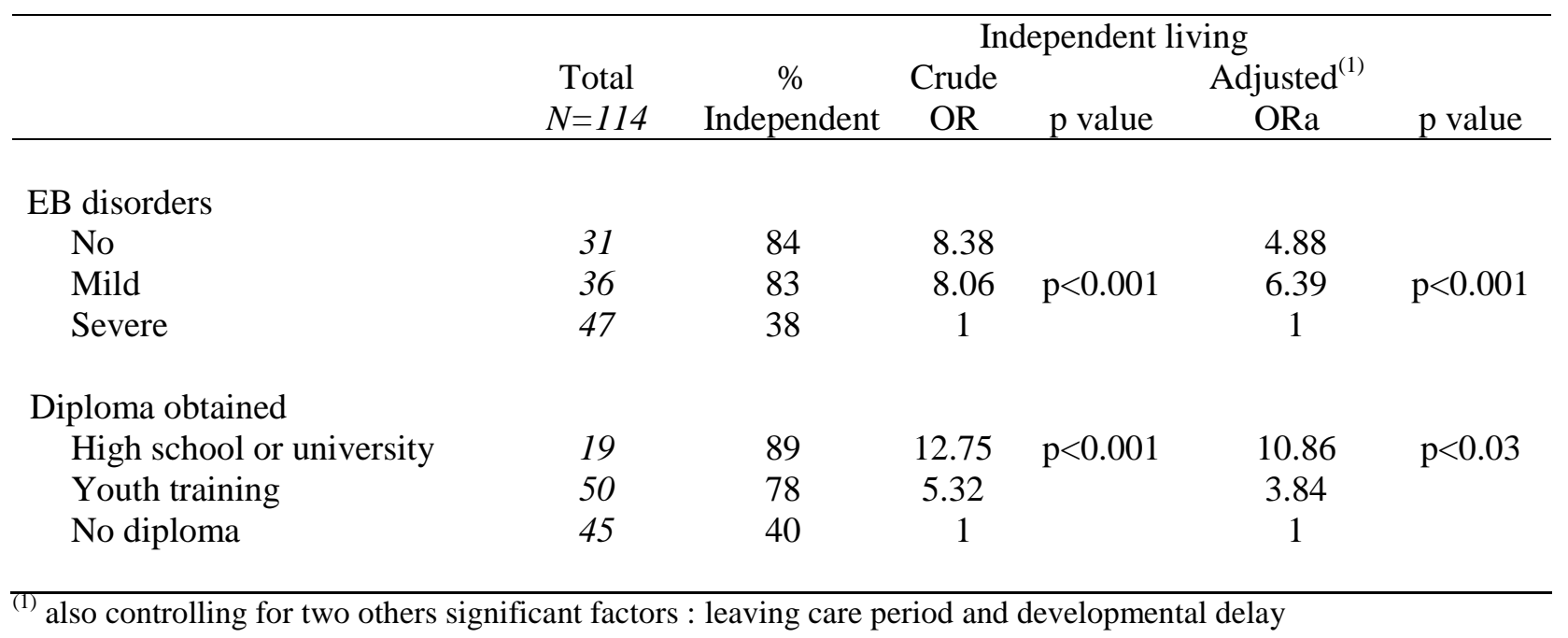

